\title{
TAMPILAN BANGUNAN SEKOLAH SEBAGAI PENANDA KAWASAN
}

\author{
Gaguk Sukowiyono \\ Dosen Prodi Arsitektur, Fak. Teknik Sipil dan Perencanaan, ITN Malang \\ e-mail: gaguk_sukowiyono@lecturer.itn.ac.id \\ Debby Budi Susanti \\ Dosen Prodi Arsitektur, Fak. Teknik Sipil dan Perencanaan, ITN Malang \\ e-mail: budisusantidebby@lecturer.itn.ac.id \\ Breeze Maringka \\ Dosen Prodi Arsitektur, Fak. Teknik Sipil dan Perencanaan, ITN Malang \\ e-mail: breezemaringka@lecturer.itn.ac.id
}

\begin{abstract}
ABSTRAK
Salah satu potensi dalam sebuah kawasan adalah menghadirkan sebuah landmark, agar bangunan yang dirancang dapat mudah ditemukan dalam lingkup suatu wilayah. Demikian juga yang kondisi yang terjadi pada SMK Widya Dharma Turen Kabupaten Malang. Kondisi rencana pengembangan sekolah tersebut berada pada lahan yang tidak terlihat langsung dari jalan arteri utama kawasan. Kajian desain dibutuhkan agar bangunan sekolah dapat mudah diketahui dan dikenali oleh masyarakat pengguna jalan, sekaligus dapat meningkatkan kualitas fisik bangunan.
\end{abstract}

Kata kunci : sekolah, bangunan, landmark

\begin{abstract}
One of the potentials in an area is to present a landmark, so that the designed building can be easily found within the scope of a region. Likewise, the conditions that occur in SMK Widya Dharma Turen Malang Regency. The condition of the school development plan is on land that is not visible directly from the main arterial road of the area. Design studies are needed so that school buildings can be easily known and recognized by the rroad user community, while improving the physical quality of the building.
\end{abstract}

Keywords : school, buildinng, landmark

\section{PENDAHULUAN}

Kenyamanan proses belajar mengajar bagi guru dan siswa merupakan syarat penting bagi keberhasilan prestasi lulusan. Demikian halnya yang dilakukan oleh SMK Widya Dharma Turen yang berada di Kecamatan Turen Kabupaten Malang. Keinginan pihak sekolah untuk melengkapi fasilitas

PAWON: Jurnal Arsitektur, Nomor 01 Volume VI, Januari - Juni Tahun 2022, ISSN 2597-7636 
ruang dan bangunan yang dibutuhkan untuk kegiatan belajar menjadi salah satu faktor penyebab yang mengharuskan pihak sekolah untuk memperluas ketersediaan lahan yang ada. Hal ini disebabkan kondisi lahan sekolah yang ada saat ini sudah dipenuhi dengan bangunan-bangunan yang berhimpitan dan dengan kondisi yang belum tertata dan terancang dengan baik. Rencana pengembangan yang diinginkan pihak sekolah adalah dengan cara memperluas area lahan sekolah kearah bagian belakang, yang selama ini dipergunakan sebagai lahan untuk lapangan olah raga dan lapangan upacara. Kendala yang kemudian ditemui adalah lahan yang menjadi rencana perluasan sekolah tidak berbatasan langsung dengan jalan raya. Sehingga pihak sekolah berencana membeli sebagian lahan untuk dipergunakan sebagaii jalan masuk ke dalam tapak. Rencana tersebut membutuhkan rancangan desain khusus yang mudah terlihat oleh pengguna jalan raya agar dapat menjadi landmark Kawasan dan mudah menemukan lokasi sekolah. Selain itu, dengan kemudahan masyarakat mengetahui dan menemukan lokasi sekolah diharapkan dapat membawa dampak berkembangnya jumlah siswa yang akan masuk ke sekolah tersebut.

\section{TINJAUAN PUSTAKA}

Landmark dapat dianggap sebagai "tetenger", yaitu penanda yang dapat membantu memudahkan menemukan suatu kawasan, lokasi maupun bangunan tertentu (Ramadan, 2019). Penanda kawasan juga dapat berupa konsep yang menyangkut aspek material pada sebuah bangunan yang diharapkan dapat memberi suatu pertanda bagi sesuatu (Scorpitaloka, 2018). Penanda juga bisa menunjukkan budaya suatu daerah untuk menunjukkan konsep perencanaan atau simbol sesuatu pada suatu wilayah (Samodro, 2020).

Tampilan visual yang menarik diharapkan dapat meningkatkan kualitas vista pada suatu kawasan yang menjadi fokus rancangan (Kawulusan, 2017). Adapun bentuk penanda kawasan salah satunya dapat berupa tanda pengenal atau identifikasi suatu lokasi (Nasruddin, 2017). Penanda pada suatu lokasi dapat menjadi isyarat ketika seseorang mencari suatu lokasi tertentu (Budiman, 2018), sehingga masyarakat pengguna jalan juga dapat terbantu dengan melihat tanda atau simbol yang secara tidak langsung menjadi penuntun ke arah mana mereka harus bergerak.

Pada sebuah kawasan perkotaan, penanda atau landmark in termasuk dalam salah satu elemen pembentuk ruang publik kota (Rahmiati, 2017). Tidak hanya berupa rambu-rambu saja (Maylajingga, 2019), penanda juga dapat berwujud bangunan bentuk dan massa bangunan yang membentuk sebuah signage (Muntiaha, 2018).

PAWON: Jurnal Arsitektur, Nomor 01 Volume VI, Januari - Juni Tahun 2022, ISSN 2597-7636 


\section{METODE PERANCANGAN}

Obyek rancangan yang akan dibahas berada pada Kecamatan Turen Kabupaten Malang, yaitu SMK Widya Dharma, dengan ukuran keseluruhan lahan adalah $15 \times 40$ meter. Obyek kaj ian ini dibatasi pada area gate atau pintu masuk kearah sekolah dimana lahan utamanya berada jauh dari tepi jalan raya. Sehingga pada pembahasan ini adalah obyek rancangan gate atau pintu masuk yang diminta oleh pihak mitra.

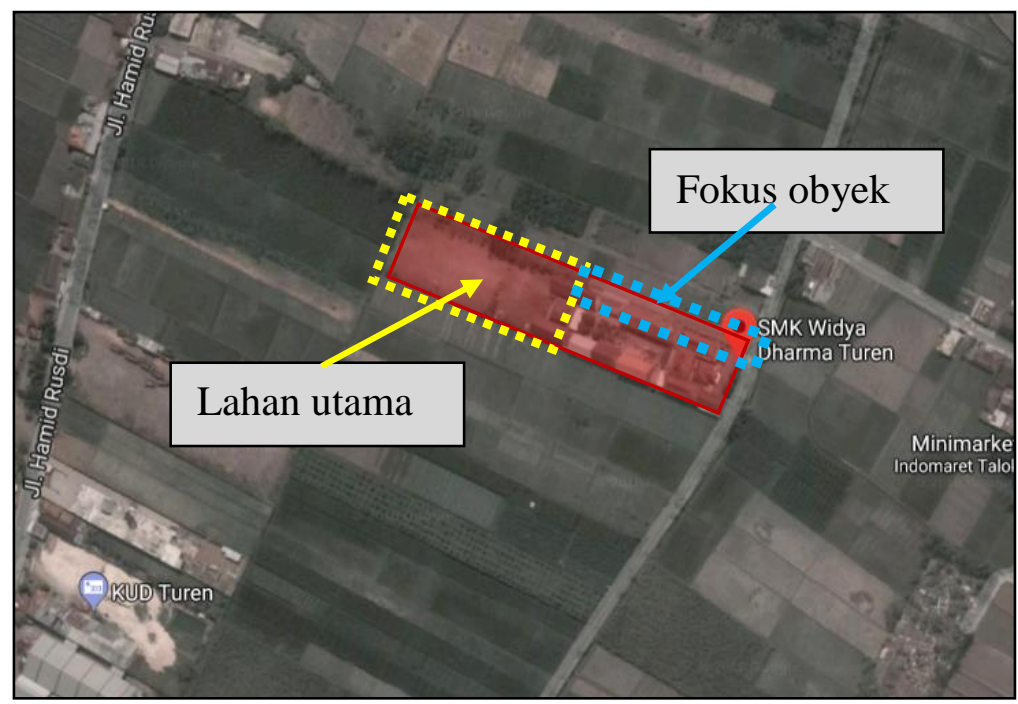

Gambar 1. Lokasi Obyek Kajian Sumber : dokumen pribadi

Metode perancangan yang digunakan dalam kajian ini adalah dengan memperhatikan kondisi eksisting kawasan dan desain bangunan utama yang sudah dilakukan sebelumnya, serta dengan mengkaji kebutuhan pengguna bangunan, dalam hal ini siswa dan tenaga pendidik. Kajian pada rancangan desain ini meliputi desain untuk area gerbang masuk sekolah dan sepanjang koridor masuk sekolah tersebut. Selain itu kajian desain juga mencakup tampilan bangunan yang dapat menjadi landmark Kawasan.

\section{HASIL DAN PEMBAHASAN}

\subsection{Kondisi Eksisting Tapak}

Kajian yang akan dibahas adalah pada bagian rencana gerbang masuk yang baru dari arah jalan raya kearah perluasan lahan sekolah. Area rencana perluasan lahan sekolah berada jauh dari arah jalan raya utama

PAWON: Jurnal Arsitektur, Nomor 01 Volume VI, Januari - Juni Tahun 2022, ISSN 2597-7636 
yang menjadi jalur sirkulasi di kawasan tersebut. Kondisi demikian menyebabkan perlunya kajian rancangan desain agar masyarakat dan pengguna jalan lebih mudah menemukan keberadaan bangunan SMK Widya Dharma Turen Kabupaten Malang.

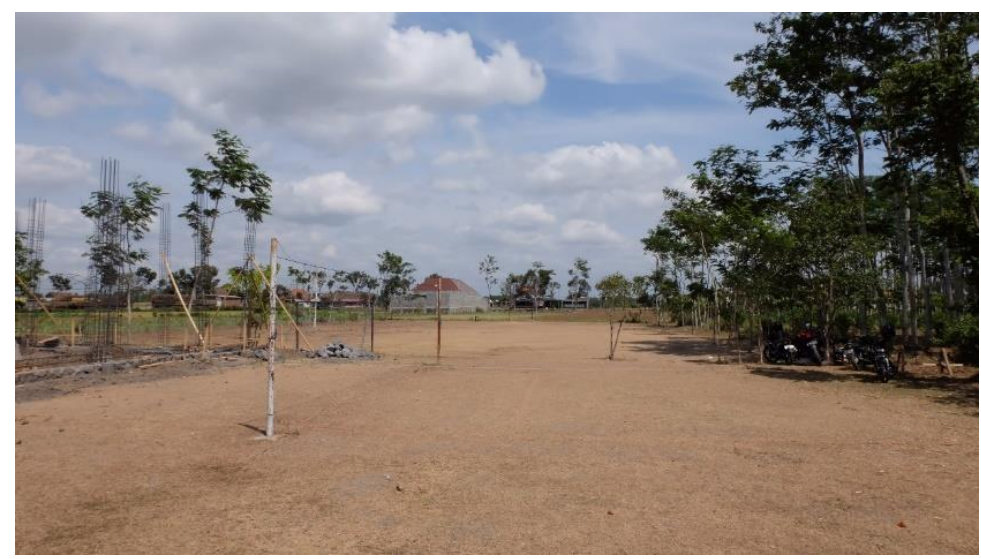

Gambar 2. Kondisi rencana perluasan lahan sekolah Sumber : dokumentasi pribadi

Akses lahan yang jauh dari tepi jalan raya menjadi penyebab bangunan sekolah tidak mudah terlihat dari arah sirkulasi jalan utama. Hal ini membutuhkan kajian desain yang mempunyai bentuk yang mudah dikenali dan area masuk yang mudah ditemukan oleh pengguna jalan. Bentuk tampilan bangunan yang mempunyai ciri khas tertentu diharapkan dapat menjadi penanda atau landmark kawasan yang mudah diingat dan dikenali oleh masyarakat sekitar dan pengguna jalan.

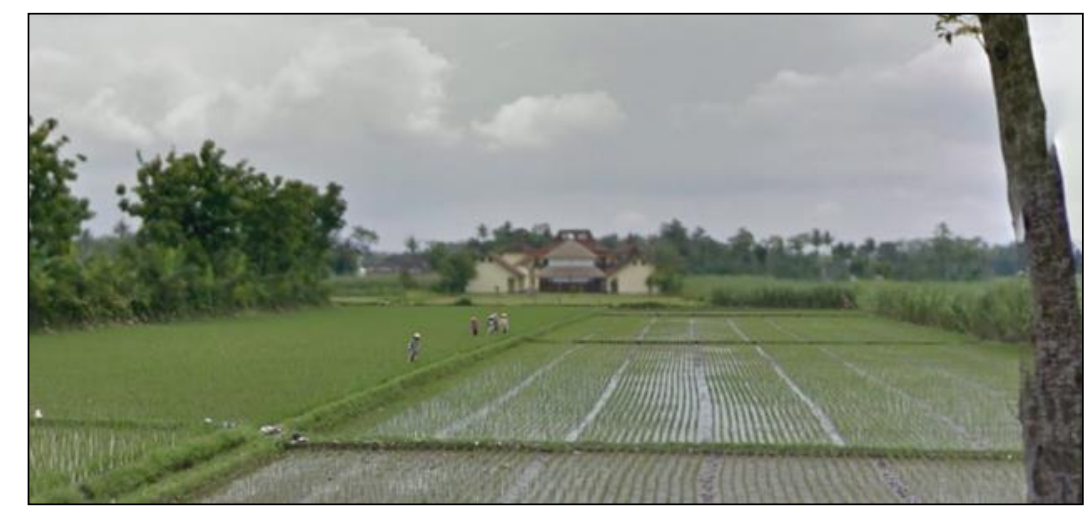

Gambar 3 Kondisieksisting banqunan sekolah dilihat dari arah jalan rava

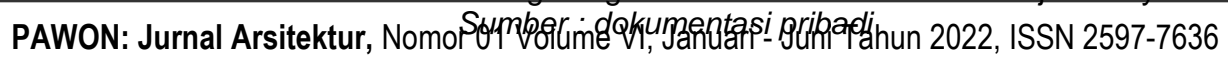


Berdasarkan gambar 3, terlihat bahwa posisi lahan sekolah jauh dari arah jalan raya utama. Sesuaikan dengan kondisi tersebut, maka dibutuhkan kajian untuk area akses masuk dan koridor sepanjang akses masuk sekolah dengan tetap memperhatikan kondisi fisik lahan dan kenyamanan pengguna bangunan. Area saat ini berupa lahan persawahan, rencana kedepannya akan menjadi area perumahan. Sehingga perlu diupayakan desain yang menarik pada bangunan sekolah dan area pintu masuknya agar mudah dikenali lokasi dan fungsi bangunan sebagai sekolah.

\subsection{Kajian Desain Tampilan Bangunan}

\subsubsection{Kajian Area Masuk dan Gerbang Sekolah}

Bagian yang dapat dianggap krusial dari obyek kajian rancangan yang diinginkan oleh pihak sekolah adalah desain area akses ke dalam area sekolah. Kondisi eksisting sekolah dengan kondisi lahan tidak berbatasan langsung dengan tepi jalan arteri primer menjadi salah satu alasan pihak sekolah membutuhkan desain khusus pada area tersebut. Rencana halaman belakang yang menjadi perluasan sekolah kurang terlihat dari arah jalan arteri utama, bahkan ketika kawasan tersebut nantinnya sudah dipenuhi oleh bangunan, kemungkinan terbesarnya adalah bangunan sekolah tersebut sama sekali tidak terlihat dari arah jalan arteri utama. Desain penanda kawasan yang dibutuhkan adalah pada area pintu masuk kawasan. Keterbatasan dana yang ada untuk membeli lahan sebagai koridor dan akses masuk menyebabkan kajian desain yang diinginkan hanya cukup untuk 1 (satu ) kendaraan roda empat saja atau 2 (dua) kendaraan roda dua berjalan berpapasan.

Berdasarkan data dan analisa yang didapatkan, jauhnya jarak antara area rencana gerbang dengan bangunan fungsi utama sekolah, maka dibutuhkan koridor yang terlindung dari panas matahari dan hujan, terutama saat siswa datang dan pulang dari sekolah. Area koridor tersebut juga harus didesain semenarik mungkin mengikuti kreatifitas usia siswa sekolah tersebut. Pada kajian desain ini, area sepanjang koridor perlu ditambahkan kanopi dengan bahan yang masih memungkinkan untuk cahaya atau sinar matahari menembus area di bawahnya, sehingga koridor tersebut tetap terang dengan pencahayaan alami di siang hari. Pemasangan kanopi tidak langsung menutup rata di sepanjang koridor yang Panjang tersebut, akan tetapi tetap diberikan area bukaan di beberapa bagian agar sirkulasi udara di area tersebut tetap lancar dan tidak terasa pengap. Selain itu bukaan di beberapa bagian atap koridor juga menghindari kesan gelap pada koridor karena lebar yang tidak terlalu besar dengan perbandingan ukuran jarak dari

PAWON: Jurnal Arsitektur, Nomor 01 Volume VI, Januari - Juni Tahun 2022, ISSN 2597-7636 
area gerbang masuk menuju area halaman utama sekolah yang cukup jauh atau panjang jaraknya.

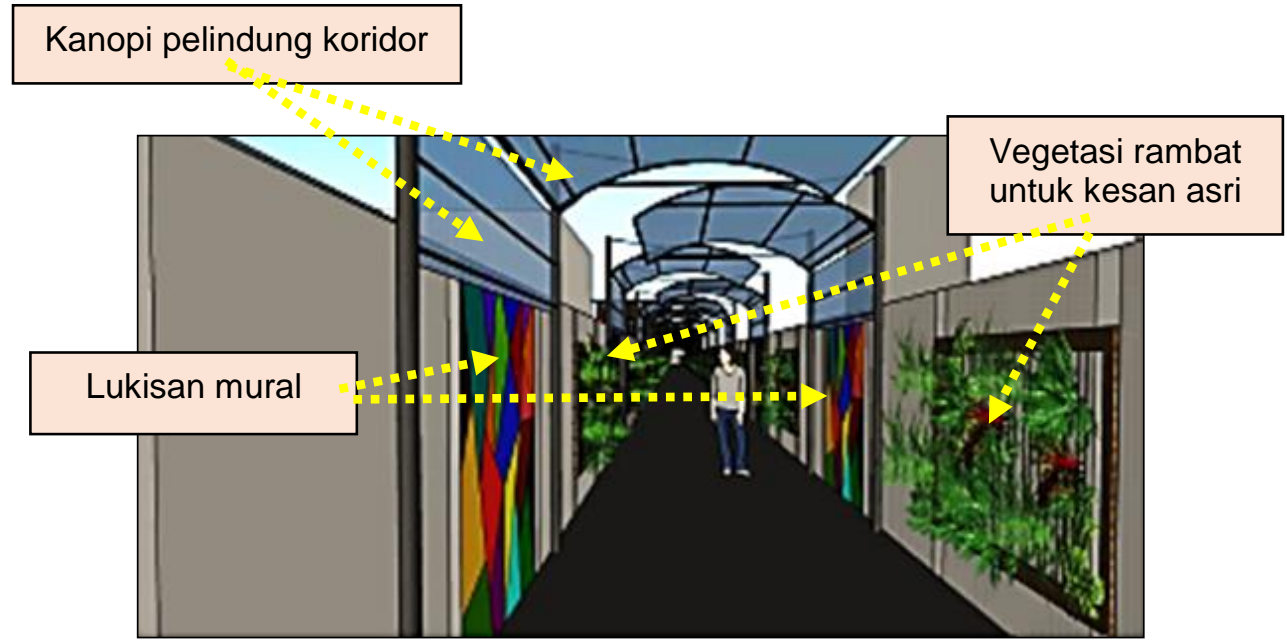

Gambar 4. Koridor area masuk sekolah

Sumber : dokumen pribadi

Selain itu, pada bagian dinding-dinding sisi koridor diberikan mural yang bisa menjadi spot untuk memamerkan bakat kreatifitas siswa sekolah tersebut. Mural di sini merupakan spot yang sewaktu-waktu bisa diganti tampilan gambarnya dan dapat menjadi wahana bagi lomba ajang kreatifitas siswa dari beberapa perwakilan kelas yang ada. Sehingga tidak hanya sekedar menjadi penghias dinding saja, tetapi juga dapat menjadi wadah edukasi bagi siswa. Selain mural, bagian dinding koridor juga diberikan tanaman rambat atau yang biasa dikenal dengan istilah vertical garden untuk memberikan kesan asri. Tanaman rambat dipilih karena posisinya yang tidak memerlukan luasan ruang pada lantai koridor, sehingga dianggap lebih hemat ruang. Selain itu penerapan media tanaman rambat juga tidak mengganggu sirkulasi pejalan kaki ataupun sirkulasi kendaraan di area sepanjang koridor. Pemasangan lampu sebagai pencahayaan buatan ditempatkan di area koridor yang tertutup kanopi sehingga kondisi lampu terlindung dari air hujan.

Penanda lokasi sekolah pada tepi jalan arteri utama dipasang papan nama sekolah. Papan nama diletakkan pada posisi yang mudah terlihat sehingga mudah untuk mengetahui keberadaan sekolah tersebut, meskipun lokasi bangunan utama masuk menjorok ke dalam seperti yang terlihat di gambar 5.

PAWON: Jurnal Arsitektur, Nomor 01 Volume VI, Januari - Juni Tahun 2022, ISSN 2597-7636 


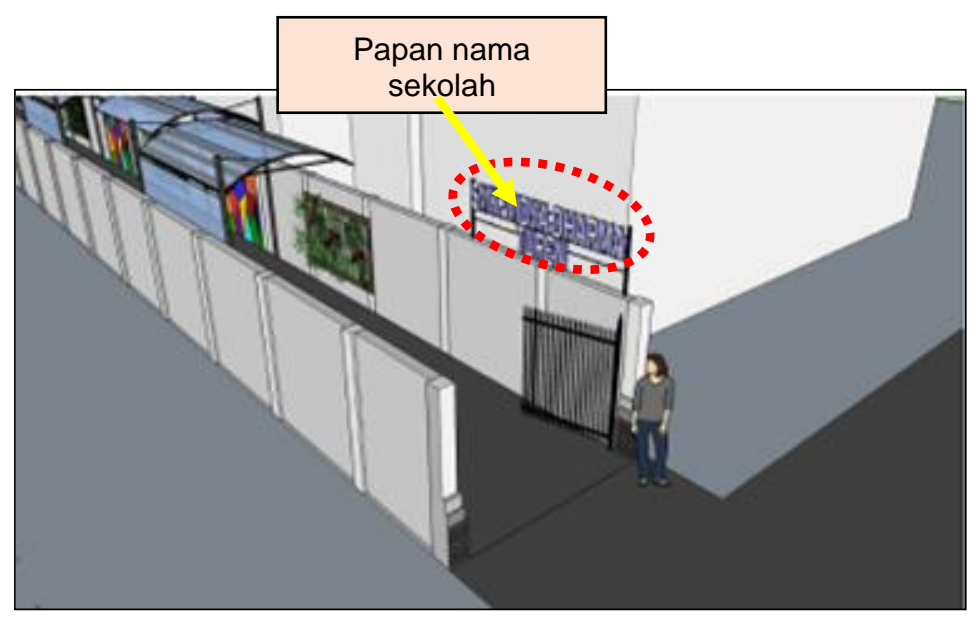

Gambar 5. Kajian penanda nama sekolah Sumber : dokumen pribadi

Koridor masuk ke area sekolah yang panjang didesain dengan menggunakan penutup alas dari bahan paving block. Alasan pemakaian paving block agar pengendara kendaraan bermotor di koridor tersebut tidak melaju kencang karena tekstur jalan yang tidak halus. Selain itu bahan paving block juga masih memungkinkan air meresap langsung ke dalam tanah sehingga bisa mencegah resiko banjir di sepanjang koridor yang sempit.

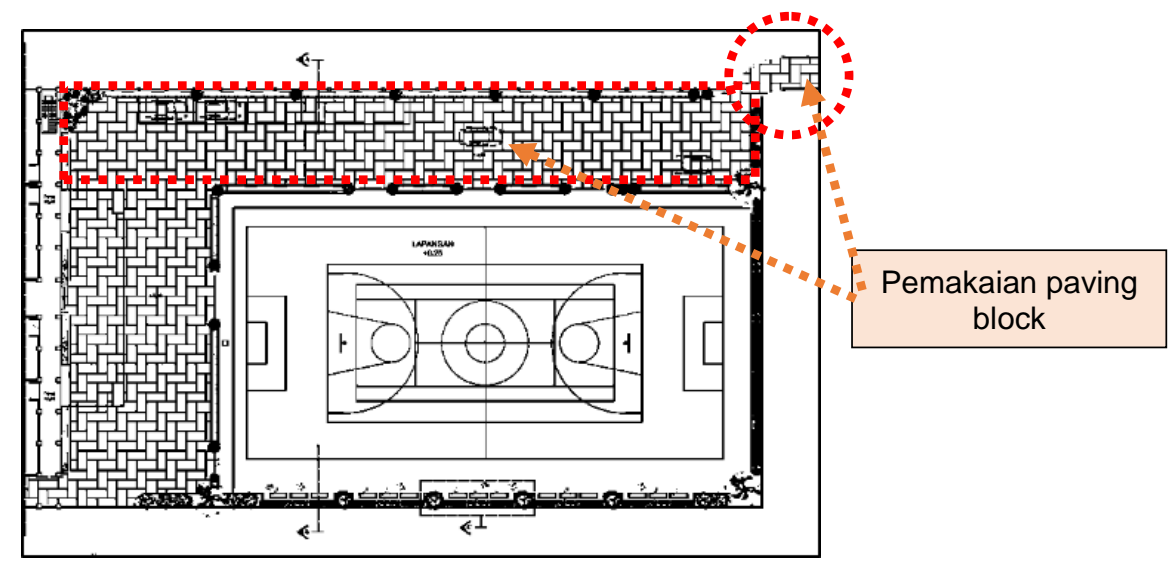

Gambar 6. Desain penutup alas koridor Sumber : dokumen pribadi

PAWON: Jurnal Arsitektur, Nomor 01 Volume VI, Januari - Juni Tahun 2022, ISSN 2597-7636 


\subsubsection{Kajian Tampilan Bangunan Sebagai Penanda Lokasi}

Penanda bangunan yang didesain untuk menjadi landmark bangunan dan juga menjadi identitas lokasi adalah bentuk kanopi dari bagian teras bangunan kelas yang sekaligus juga memiliki fungsi sebagai area penerima sekolah, kantor dan ruang guru. Kanopi bangunan tersebut didesain memiliki ukuran yang besar dan tinggi supaya mudah terlihat dari arah jalan raya. Bagian kanopi teras didesain dengan bentuk unik dan ukuran besar agar tetap dapat terlihat jika nanti di waktu yang akan datang lahan kosong yang berada di depan sekolah sudah tertutup bangunan. Selain ukurannya yang besar dan bentuknya yang unik, warna kanopi teras bangunan didesain dengan warna yang dominan dan dapat menjadi pembeda dari bangunan lainnya.

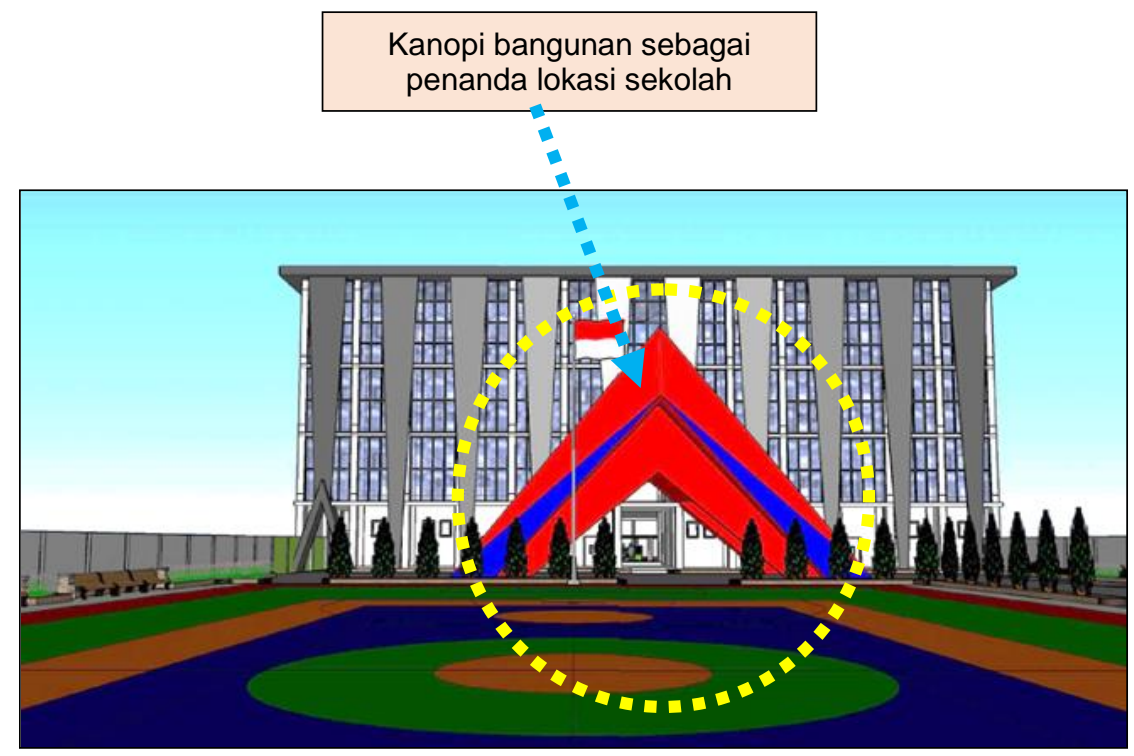

Gambar 7. Kanopi bangunan sebagai penanda lokasi Sumber : dokumen pribadi

Pada gambar 7 terlihat kanopi rencana bangunan kelas baru didesain dengan tinggi yang hampir menyamai tinggi bangunan berlantai empat, sehingga diharapkan dengan desain tersebut kanopi bangunan sebagai penanda lokasi sekolah dapat tetap terlihat meskipun lahan di depan sekolah nantinya sudah tertutup bangunan. Warna merah pada kanopi

PAWON: Jurnal Arsitektur, Nomor 01 Volume VI, Januari - Juni Tahun 2022, ISSN 2597-7636 
sengaa didesain agar mudah terlihat dari jarak jauh karena warnanya yang berbeda dan kontras dengan warna bangunan utamanya. Atap kanopi didesain dengan menggunakan bahan yang terbuat dari aluminium composite panel (ACP).

\section{KESIMPULAN}

Penanda kawasan merupakan salah satu unsur pembentuk kawasan yang dapat menjadi pengarah laju pergerakan menuju suatu posisi atau lokasi. Tidak hanya berupa rambu-rambu saja, bentuk tampilan bangunan juga dapat menjadi penanda lokasi, bahkan dapat juga menjadi landmark sebuah kawasan, yang secara tidak langsung dapat meningkatkan kualitas dari bangunan tersebut dalam sebuah kawasan.

Begitu juga dengan bangunan sekolah yang menjadi fokus kajian ini. Keberadaan lokasi sekolah yang berada pada posisi menjorok ke dalam dari arah jalan raya atau jalan arteri utama kawasan, sangat membutuhkan kajian desain yang mampu menjadi penanda atau landmark kawasan agar tidak mudah 'tenggelam' di antara bangunan-bangunan yang ada di depan lokasi sekolahnya. Area gerbang masuk dan koridor masuk yang tidak terlalu besar, mengakibatkan perlunya kajian desain tampilan bangunan yang dapat mendukung posisinya sebagai landmark.

\section{DAFTAR PUSTAKA}

Samodro. (2020, Januari). Landmark sebagai Penanda yang Memberi Makna Dalam Pencitraan Kota Kajian Tugu Bundaran Pamulang di Tangerang Selatan. Jurnal Adat-Jurnal Seni, Desain \& Budaya Dewan Kesenian Tangerang Selatan, 2(1), 1-9.

Maylajingga, N. (2019, Mei). Kajian Elemen Perancangan Hamid Shirvani Pada Kawasan Kota Satelit. Jurnal Arsitektur PURWARUPA, 3(2), 123-130.

Maymun, A. Z. (2018). Identitas Visual Dan Penerapannya Pada Signage Untuk Kawasan Wisata Edukasi. Serat Rupa Journal of Design, 2(1), 1-13.

Muntiaha, G. I. (2018). Penerapan Konsep Urban Tourism pada Perancangan Permukiman Sindulang Sati di Manado. Jurnal Fraktal, 41-50.

Ramadan, M. B. (2019). Elemen Pembentuk Citra Pusat Kota Jepara Berdasarkan Peta Mental Masyarakat. Arcade Jurnal Arsitektur, 3(2), 100-107. 
Scarpiitaloka, R. D. (2018). Penerapan Aspek Material untuk Penanda Kawasan Waduk Jatigede. e-Proceding of Art \& Design (pp. 1-10). Bandung: Telkom University.

Budiman, I. T. R. (2018). Analisis Eleen-Elemen Pembentuk Citra Kota di Kawasan Perkotaan Tahuna Kabupaten Kepulauan Sangihe. Jurnal Spasial, 5(2), 190-199

Nasruddin. (2017). Penataan Tata Informasi Sebagai Visual Kawasan di Koridor Jamin Ginting Pancur Batu. Prosiding Seminar Kearifan Lokal dan Lingkungan Binaan. (pp. 980-992).

Kawulusan, M. (2017). Perancangan Public Landmark Pada Ruang Terbuka Publik. Media Matrasain, 14(3), 39-51.

Rahmiati, D. (2017). Kajian Elemen Pembentuk Ruang Kota Pada Ruang Terbuka Publik Kota. Ikraith-Teknologi, 1(2), 1-8 